\title{
Türkiye'nin Virüs Savar Bitkisi Laden (Cistus spp.) Türleri: Geleneksel Kullanımları, Biyoaktif Kimyasal Bileşenleri ve Farmakolojik Aktiviteleri*
}

\author{
Rockrose (Cistus spp.) Species as Turkey's Virus Repellent Plants: Traditional Uses, Bioactive Chemical \\ Components and Pharmacological Activities
}

Nazım Şekeroğlui, Sevgi Gezicii

'Prof. Dr., Kilis 7 Aralık Üniversitesi, Ziraat Fakültesi, Bahçe Bitkileri Bölümü. İleri Teknoloji Araştırma ve Uygulama Merkezi, Tıbbi ve Aromatik Bitkiler Laboratuvarı, https://orcid.org/0000-0002-0630-0106

iiDoç. Dr., Kilis 7 Aralık Üniversitesi, Fen-Edebiyat Fakültesi, Moleküler Biyoloji ve Genetik Bölümü. Ileri Teknoloji Araştırma ve Uygulama Merkezi, Genetik Araştırma Laboratuvarı, https://orcid.org/0000-0002-4856-0221

öz

Cistaceae familyasından olan Cistus (Laden) türleri; çok yıllık, çalı formunda, beyaz veya pembe çiçekli, genellikle Orta Doğu Akdeniz (Fransa ve ỉber Yarımadası hariç), Kuzey Afrika ve Batı Asya'da yayılım gösteren bitki türleridir. C. creticus L. (sinonim Cistus $\mathrm{x}$ incanus subsp. creticus (L.) Hetwood), C. salviifolius L., C. parviflorus Lam., C. monspeliensis L. ve C. laurifolius L. türleri Türkiye florasında doğal olarak yetişmekte olan, ekonomik ve endüstriyel öneme sahip laden taksonlarıdır. Bu bitkiler; halk arasında 'laden', 'Iaden otu', 'kaya gülü', 'pamukla', 'pamukluk', 'pamuk otu', 'davşanotu', 'karağan' ve 'tavşançalısı' olarak bilinmektedir. Laden türlerinin yaprakları, çiçekleri, tohumları rezin ve uçucu yağları; Anadolu Halk Hekimliğinde, infüzyon halinde kabızlık giderici, uyarıcı, balgam söktürücü, mide ve romatizmal hastalıkların tedavisinde, ayrıca mikroorganizma enfeksiyonlarına karşı koruyucu ve tedavi edici olarak yüzyıllardır geleneksel olarak kullanılmaktadır. Cistus türleri ihtiva ettikleri quercetin, myricetin, kaempferol, kaempferol-3-metil eter, apigenin, luteolin, aesculin, flavan-3-ol ve proantosiyanidin gibi oldukça farklı fitokimyasal içeriğe sahip olup, içerdiği bu doğal bileşikler sayesinde tıp alanında kullanımlarına yönelik antiviral, antimikrobiyal, antifungal, antioksidan, antienflamatuvar, antispazmodik ve antidiyabetik özelliklere sahip olduğunu rapor eden birçok bilimsel çalışma bulunmaktadır. Bu derlemede; ülkemizin en önemli virüs savar bitkilerinden olan Cistus türlerinin Anadolu geleneksel halk hekimliğindeki kullanımlarının yanı sıra; fitokimyasal bileşimleri, farmakokinetikleri, farmakolojik ve biyolojik aktiviteleri bilimsel veriler ışığında kapsamlı olarak sunulmuştur.

Anahtar Kelimeler: Cistus spp., Laden, Şifalı bitki, Antiviral, Anadolu Halk Hekimliği

ABSTRACT

Cistus (Rockrose) species from the Cistaceae family; perennial, bush-shaped, with white or pink flowers, generally spread in the Middle East Mediterranean (except France and Iberian Peninsula), North Africa and Western Asia. C. creticus L. (sinonim Cistus $\mathrm{x}$ incanus subsp. creticus (L.) Hetwood), C. salviifolius L., C. parviflorus Lam., C. monspeliensis L. and C. laurifolius L. species, growing naturally in Turkey flora, have economic and industrial importance. Cistus species are traditionally known as 'laden', 'laden otu', 'kaya gülü', 'pamukla', 'pamukluk', 'pamuk otu', 'davşanotu', 'karağan' and 'tavşançalısı' in different parts of Turkey. Leaves, flowers, seeds, resin and essential oils of Rockrose species have been traditionally used for centuries as infusions for laxative, stimulant, expectorant, treatment of stomach and rheumatic diseases as well as preventive and therapeutic against microorganism infections in the Anatolian folk medicine. Cistus species have quite different phytochemical contents such as quercetin, myricetin, kaempferol, kaempferol-3-methyl ether, apigenin, luteolin, aesculin, flavan-3-ol and proanthocyanidin, and there are many scientific studies reporting that they possess antiviral, antimicrobial, antifungal, antioxidant, anti-inflammatory, antispasmodic and antidiabetic properties. In this review; traditional uses, phytochemical compositions, pharmacokinetics, pharmacological and biological activities of Cistus species, one of the most important antiviral plants in Anatolian traditional medicine, are presented in the light of scientific literature.

Keywords: Cistus spp., Rockrose, Medicinal plant, Antiviral, Anatolian Folk Medicine

${ }^{*}$ Lokman Hekim Dergisi, 2021; 11 (2): 258-268

DOI: 10.31020/mutftd.895397

e-ISSN: 1309-8004, ISSN 1309-761X

Geliş Tarihi - Received: 11 Mart 2021; Kabul Tarihi - Accepted: 30 Nisan 2021

iletişim - Correspondence Author: Nazım Şekeroğlu <sekeroglu@kilis.edu.tr> 


\section{Giriş}

Geleneksel ve tamamlayıcı tıp, özellikle de bitkisel tedavi uygulamaları, tüm dünyada ve ülkemizde, özellikle son yıllarda, tedavisi zor veya imkânsız hastalıkların tedavisinde önem taşımaktadır. Kanser, diyabet, kardiyovasküler hastalıklar, nörodejeneratif bozukluklar ve son yıllarda giderek yaygınlaşan viral enfeksiyonlar başta olmak üzere pek çok hastalıktan korunmak, bu hastalıkların tedavisinde, hastalık süreci ve sonrasında insanların yaşam kalitesini artırmak amacıyla bitkisel tedavi yöntemleri giderek artan bir ivme kazanmıştır. ${ }^{1-3}$

Antik çağlardan bu yana bitkiler tedavi amacıyla kullanılmakta olup, her geçen gün tedavi amacıyla kullanılan bitkilerin sayısında ciddi bir artı̧̧ gözlenmektedir. XIX. yüzyılın başlarında tedavi amacıyla kullanılan bitki sayısının 13.000 civarında olduğu bilinmektedir. Son yıllarda tıbbi bitkiler ve bunlardan elde edilen etken maddeler ve / veya bileşenler üzerindeki çalışmalar tıbbi ve aromatik bitkilere olan ilginin artmasına neden olmuştur. Ülkemizde yaklaşık 650 tıbbi bitki bulunurken, dünyada bu sayı 360.000 civarındadır. Ülkemizde genel yaygınlığı tam olarak bilinmemekle birlikte tedavi amacıyla tıbbi özellikleri bilinen bitkilerin kullanıldığı pek çok geleneksel hekimlik uygulamasının mevcut olduğu bilinmektedir., ${ }^{1,45}$

Virüsler oldukça küçük mikrobiyal canlılar olup, genetik materyalleri bir protein kılıf ile kaplıdır. Virüsler genellikle, soğuk algınlığı, grip ve siğiller gibi bilinen bulaşıcı hastalıklara neden olurlar. Ayrıca, son yıllarda insanlığın sağlığını tehdit eden ve hatta pandemi seviyesine ulaşan HIV / AIDS, Ebola ve KOVID-19 gibi ciddi hastalıkların da nedeni virüslerdir. ${ }^{6}$ Virüsler, diğer bir ifadeyle, korsanlar gibidirler; normal canlı hücreleri istila ederler ve bu hücreleri konak olarak kullanıp, bu hücrelerin içinde kendileri gibi başka virüsleri üretirler. Dolayısıyla, sağlıklı ve canlı hücreler, virüs enfeksiyonları ile hasar görür, yapısal olarak değişime uğrar veya hayatiyetini kaybeder. Böylelikle, viral enfeksiyona yakalanan insanlar farklı hastalıklar ile tanışırlar. ${ }^{7,8}$ Virüsler genellikle, insan vücudundaki karaciğer, solunum sistemi veya kan hücrelerine saldırırlar. İnsan vücuduna giren her virüsün hastalık yapma yetisi yoktur veya güçlü bağışıklık sistemleri bu virüsleri rahatlıkla alt edebilirler. Virüs kaynaklı hastalıklarda antibiyotikler işe yaramazken, bazı antiviral ilaçların etkili olduğu viral enfeksiyonlar da bulunmaktadır. Geliştirilen aşıların bir kısmı ise; viral enfeksiyonların hafif geçmesine yardımcı olabilmektedir. ${ }^{6-9}$

Uluslararası Virüs Taksonomisi Komitesi (ICTV), insanları enfekte edebilen 23 familyaya ait 219 farklı virüs türünün bulunduğunu ve her yıl üç ila dört farklı virüs türünün tespit edildiğini bildirmektedir. İnsanlarda enfeksiyona neden olan virüslerin birçoğu aynı zamanda memeliler ve kuşlarda da enfeksiyona yol açabilmekte ve bu canlıları konakçı olarak kullanabilmektedirler. Son yıllarda insanlarda enfeksiyona yol açan virüslerin birçoğunun kaynağının da bu canlılar olduğu belirtilmektedir. İnsanlarda enfeksiyona neden olan canlıların üçte ikiden fazlasını virüsler oluşturmaktadır. İnsanlarda enfeksiyona sebep olduğu bilinen ilk virüs 1901 yılında keşfedilen Sarı Humma Virüsü (Flavivirüs ailesine ait bir RNA virüsü)'dür., ${ }^{70}$ Insanlık tarihinde, dünya çapında, salgınlara neden olan ölümcül viral enfeksiyonlar; Kolera, Ebola, AIDS (Acquired Immunodeficiency Syndrome), Influenza, SARS (Severe Acute Respiratory Syndrome), MERS (Middle East Respiratory Syndrome), ve en son dünyayı kasıp kavuran KOVID-19 (yeni tip koronavirüs, 2019-nCoV ve SARS-CoV-2 virüsü) pandemisidir. Bugüne kadarki en etkili ve yaygın virüslerden olan KOVID-19, aslında önceki virüs salgılarına epidemi, sosyal ve ekonomik etkileri bakımından benzerlik göstermektedir. Önceki virüs salgınlarına ve virüslere göre farkı sadece virüsün biyolojik özellikleri, yüzey proteinlerinin yapısı ve enfeksiyon mekanizmasıdır. ${ }^{11-14} \mathrm{Her}$ ne şekilde olursa olsun viral enfeksiyonlar, insanoğlunun kolaylıkla başa çıkamadığı, korunma ve tedavi yöntemlerinin zor bulunduğu mikrobiyal hastalıklar olarak bilinmektedir. Bu nedenle, geniş spektrumlu antiviral bitkilerin tespiti ile bu bitkilerden doğal tedavi ürünlerinin geliştirilmesi insanlığın geleceği açısından önem taşımaktadır. 
Özellikle son yıllarda viral enfeksiyonların ortaya çıkma aralığının oldukça daralması, çoğunlukla yabani veya evcil hayvanlardan bulaşan virüslerin insanlar üzerindeki etkilerinin ciddi sonuçlara ulaşması ve viral enfeksiyonların tedavisinde kullanılabilecek ilaçların bulunmaması veya geliştirilememesi, aşı çalışmalarının yavaş ve yetersiz kalması sonucunda hastalığın geride tedavisi güç sağlık sorunları bırakması veya toplu ölümlere yol açması virüslerle mücadelede geleneksel ve tamamlayıcı tıp uygulamalarının önemini bir kez daha ortaya koymaktadır. Zengin bitki biyoçeşitliliği ile ülkemiz özellikle bitkisel tedaviler konusunda oldukça avantajlı bir konumda görülmektedir. Bu bağlamda, tıbbi ve aromatik bitkiler ihtiva ettikleri zengin biyoaktif bileşikler ve sekonder metabolitler ile virüslerin neden olduğu hastalıklar başta olmak üzere pek çok mikrobiyal hastalı̆̆ın tedavisinde ve gelişiminin engellenmesinde 'alternatif tıp (bitkisel tedavi)' olarak yadsınamaz derecede önem arz etmektedir. Yapılan araştırmalar sadece viral enfeksiyonlar değil, sağıkık bireylerde de bitkisel ürün kullanımına yönelik artan bir ilginin olduğunu göstermektedir. ${ }^{15,16}$

Bu kapsamda, ülkemizde doğal olarak yetişen ve antiviral özellikleri ile özellikle Avrupa'da gerek ilaç sanayisinin gerekse bilim camiasının dikkatini çeken, ancak ülkemizde doğadan en fazla toplanan ilk üç bitki arasında yer alan ve dış ticareti yapılan, Cistus spp. (Laden) türleri bu derlemenin konusunu oluşturmuştur. Bilimsel veriler ışığında hazırlanan bu derlemede, Cistus spp. (Laden) türlerinin; coğrafik dağııımı ve botanik özellikleri, biyoaktif kimyasal bileşenleri, geleneksel kullanımları, antiviral kapasiteleri özelinde biyolojik ve farmakolojik aktiviteleri ele alınmıştır.

\section{Coğrafik Dağııımı ve Botanik Özellikleri}

Ladengiller (Cistaceae) familyası, genel olarak Akdeniz iklim kuşağında yayılım gösteren, maki vejetasyonunda yetişen ağaç̧̧ı, yarı çalı veya otsu bitkilerden oluşan bir bitki familyasıdır. Familya Dünya genelinde dokuz cins ve yaklaşık 200-250 kadar bitki türü intiva etmekle birlikte; Helianthemum, Halimium, Fumara, Tuberaria ve Cistus cinsleri en yaygın olanlarıdır. ${ }^{17-19}$ Önemli cinslerinden biri Cistus (laden)' dur, laden cinsine ait bitki türleri Güney Avrupa ile Kuzey Afrika orijinli olup, Akdeniz iklim kuşağında taşlı ve kiremitli açık alanlarda yayılış gösterirler. Çok yıllık veya çalımsı yapıda olan Laden türleri, her dem yeşil veya kısmen yeşil olan bitki türleridir. Yaprakları basit tüylü ve yapışkan, boyu $30 \mathrm{~cm}$ ile $100 \mathrm{~cm}$ arasında olabilen, beyaz, pembe ve koyu pembe renkli gösterişli çiçeklere sahip olan bitkilerdir. Cistus cinsi, Dünya'da yaklaşık 50 farklı tür intiva etmekte ve bu türler genellikle kayalık alanlarda, kuru ve ılıman bölgelerde yayılış göstermektedir. ${ }^{1,19,20}$ Türkiye florasında bu cinse ait 5 tür tanımlanmıştır. Bunlar: $C$. creticus L. (sinonim Cistus x incanus subsp. creticus (L.) Hetwood), C. salviifolius L., C. parviflorus Lam., C. monspeliensis L. ve $C$. laurifolius L. türleridir. ${ }^{119,21,22}$ Türkiye'de yayılış gösteren Cistus türlerinin sistematik bilgileri ve taksonlar ile ilgili genel bilgiler Tablo 1 ve Tablo $\mathbf{2}^{\prime}$ de sunulmuştur.

Tablo 1. Türkiye'de yayılış gösteren Laden (Cistus spp.) türlerinin taksonomik açıdan sınıflandırılması Kingdom Plantae

Subkingdom Tracheobionta

Division Magnoliophyta

Class Magnoliopsida

Subclass Dilleniidae

Order Violales

Family Cistaceae

Genus Cistus

Species Cistus creticus L. (sinonim Cistus x incanus subsp. creticus (L.) Hetwood)

Cistus salviifolius L.

Cistus parviflorus Lam.

Cistus monspeliensis L.

Cistus laurifolius L. 
Tablo 2. Türkiye'de yayılış gösteren Laden (Cistus spp.) türlerinin genel özellikleri

\begin{tabular}{|c|c|c|c|c|c|}
\hline Genel Bilgiler* & C. creticus L. & C. salviifolius L. & C. parviflorus Lam. & C. monspeliensis $L$. & C. Iaurifolius L. \\
\hline Ömür & Çok yıllık & Çok yıllık & Çok yıllık & Çok yıllık & Çok yıllık \\
\hline Yapı & Çalı & Çalı & Çalı & Çalı & Çalı \\
\hline Çiçeklenme & $3-6$ & $3-5$ & $3-4$ & Bilinmiyor & $5-6$ \\
\hline Habitat & Maki, garik & $\begin{array}{l}\text { Sahil tepesi kalkerli } \\
\text { maki, garik }\end{array}$ & Kalkerli garik & Maki & $\begin{array}{l}\text { Maki, Pinus nigra } \\
\text { ormanı }\end{array}$ \\
\hline Yükseklik & $0-1000$ & $0-500$ & $0-100$ & $-1--1$ & $50-1200$ \\
\hline Endemik & Endemik değil & Endemik değil & Endemik değil & Endemik değil & Endemik değil \\
\hline Element & Omni Akdeniz & Bilinmiyor & Doğu Akdeniz & Akdeniz & Akdeniz \\
\hline Türkiye Dağılımı & $\begin{array}{l}\text { Kuzey, Batı ve } \\
\text { Güney Türkiye }\end{array}$ & $\begin{array}{l}\text { Kuzey ve Batı } \\
\text { Türkiye, } \\
\text { Anadolu }\end{array}$ & $\begin{array}{l}\text { Güney ve Batı } \\
\text { Türkiye }\end{array}$ & Batı Anadolu & $\begin{array}{l}\text { Kuzey, Batı, Güzey } \\
\text { ve Orta Anadolu }\end{array}$ \\
\hline Genel Dağılımı & $\begin{array}{l}\text { Kırım, Orta Avrupa } \\
\text { ve Gürcistan, } \\
\text { Akdeniz }\end{array}$ & $\begin{array}{l}\text { Akdeniz, Kuzey } \\
\text { İran'a, Kafkasya, } \\
\text { Batı Avrupa }\end{array}$ & $\begin{array}{l}\text { Doğu Akdeniz, } \\
\text { İtalya'dan Kıbrıs'a }\end{array}$ & Akdeniz & $\begin{array}{l}\text { Akdeniz, Batı ve } \\
\text { Orta Avrupa }\end{array}$ \\
\hline
\end{tabular}

*TUBIVES, Aralık 2020 verilerinden yararlanılarak oluşturulmuştur. ${ }^{22}$

Türkiye florasında yayılış gösteren C. creticus L. (sinonim Cistus $x$ incanus subsp. creticus (L.) Hetwood), C. salviifolius L., C. parviflorus Lam., C. monspeliensis L. ve C. laurifolius L. türlerinin coğrafik dağılımları Şekil 1'de verildiği gibidir. Türlerin şehirlere göre coğrafik dağıımını gösteren harita TUBiVES (Türkiye Bitkileri Veri Servisi, versiyon 2.0 BETA) verilerinden alınmış olup, her bir renk farklı bir Cistus türünü temsil etmektedir. ${ }^{22}$

C. creticus L. ve C. salviifolius L. türlerinin Türkiye'de genel olarak Kuzey, Batı ve Güneydoğu Anadolu Bölgelerinde yayılış gösterdiği bilinmekle birlikte; C. creticus L. türü Bolu, İstanbul, Karabük, Antalya, Aydın, Çanakkale, İçel, İzmir, Kahramanmaraş, Ordu, Rize, Sinop ve Trabzon illerinde; C. salviifolius L. türü ise Düzce, İstanbul, Antalya, Çanakkale, Erzurum, Hatay, İçel, Rize, Samsun, Trabzon ve Aydın illerinde doğal olarak bulunmaktadır. C. parviflorus türü İçel, Muğla ve Tekirdağ illerinde; $C$. monspeliensis türü genel olarak İzmir'de ve C. laurifolius ise Adana, Kastamonu, Ankara, Bursa, Denizli, İzmir, Kütahya, Sinop ve Yozgat illerinde yayılış göstermektedir (Şekil 1).

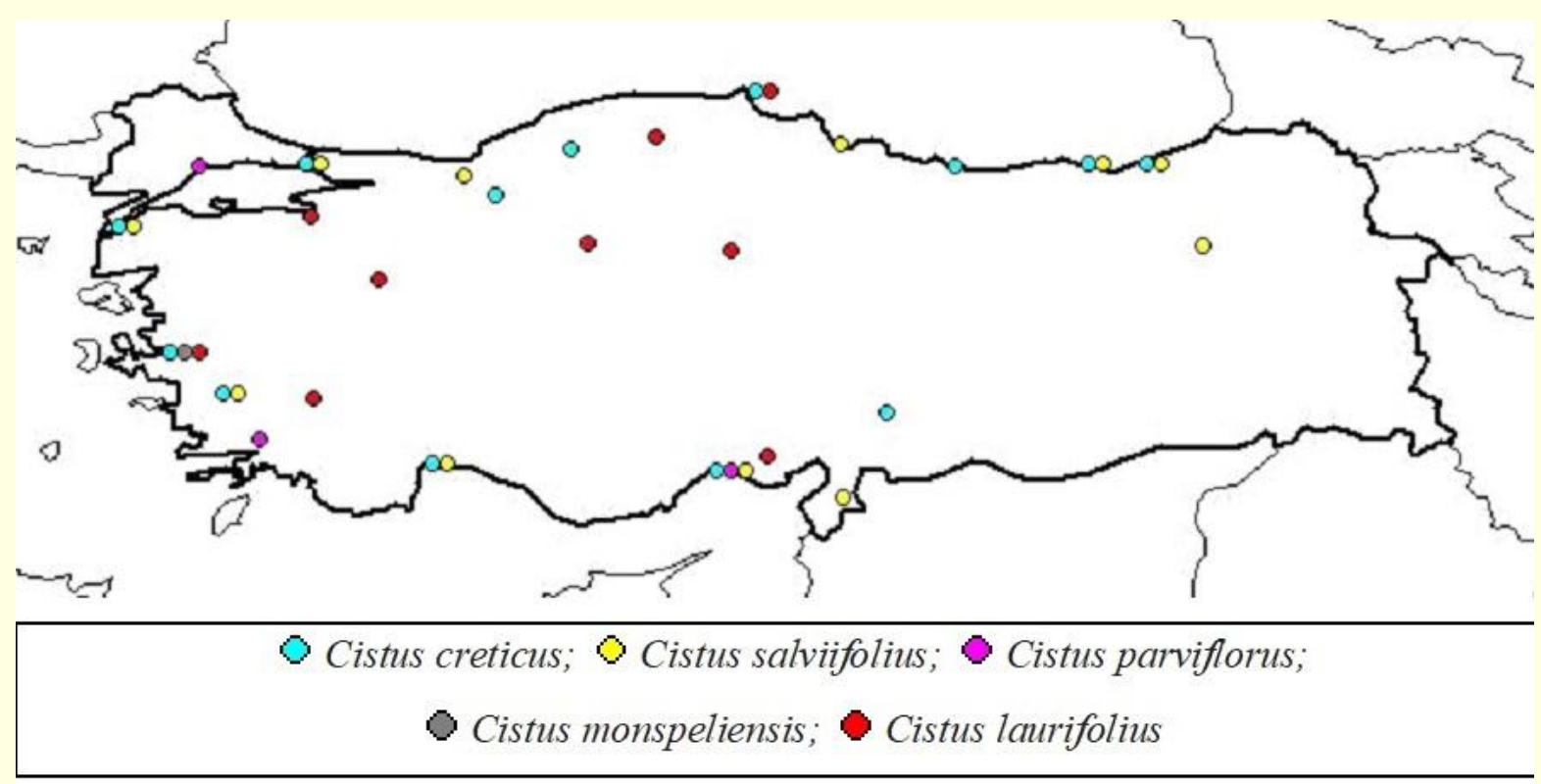

Şekil 1. Laden (Cistus spp.) türlerinin Türkiye'de bölge ve şehirlere göre coğrafik yayılışı

\section{Cistus (Laden) Türlerinin Biyoaktif Kimyasal Bileşenleri}

Cistus kelimesi Yunanca'da "Kist" yani "Kutu" anlamına gelmekte ve bu tanımlama bitkinin tohumlarının bulunduğu kapsüllerin şeklinden ileri gelmektedir. "Laden”, "Ladanum" veya "Labdanum" olarak 
adlandırılan esmer renkli, hoş kokulu, akambere benzeyen, parmaklar arasında kolaylıkla ezilip yumuşayan, tadı acımsı, yakıcı ve kolay yanabilen 'oleoresin' maddesi özellikle Cistus albiflorus, Cistus creticus, Cistus ladanifer ve Cistus maculatus türlerinden elde edilmektedir. Laden türlerinden elde edilen bu 'oleoresin' maddesi, balinalardan elde edilen 'ambergris' maddesinin bitkilerdeki yegâne eşdeğeri olarak bilinmektedir. Geçmişte yapışkan özelliğe sahip oleoresin maddesi, Cistus bitkileri arasında otlayan koyun ve keçilerin yünleri üzerinden taranıp toplanarak elde edilirken; günümüzde ise bitkinin yapraklı dallarının suda kaynatılması ve dibe çöken oleoresinlerin toplanması şeklinde elde edilmektedir. Özellikle pahalı parfümlerin üretiminde kullanılan oleoresin, distilasyon yöntemi ile Cistus uçucu yağından elde edilmekte ve Fransa, İspanya başta olmak üzere bazı ülkelerde ticari olarak üretilmektedir. ${ }^{20,23}$

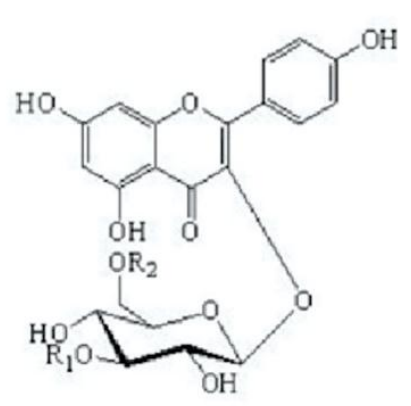

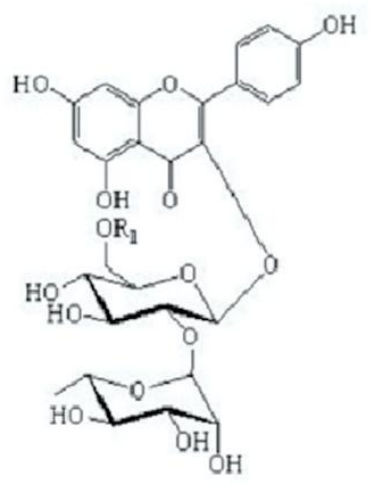

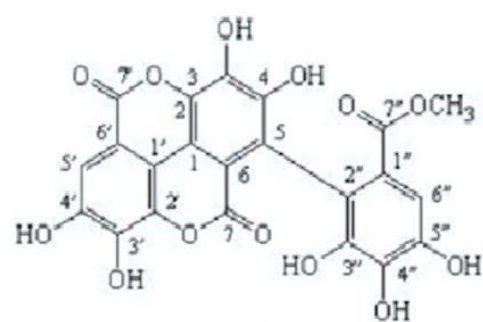

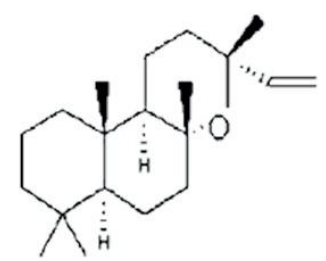<smiles>C=C[C@]1(C)CC[C@@H]2C(C)(C)CCC[C@]2(C)[C@@H]1C</smiles><smiles>CC1CCC2C(C)(C)CCC[C@]2(C)[C@H]1CO</smiles><smiles>Oc1ccc(O)cc1</smiles><smiles>Oc1ccc(OC2CC(O)C(O)C(O)C2O)cc1</smiles><smiles>COC1OCC(O)C(O)C1O</smiles><smiles>O=C(O)C1CC(O)C(O)C(O)C1</smiles><smiles>COc1cc2c(cc1O)OC(=O)CC2</smiles>

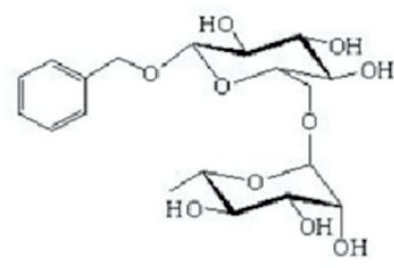

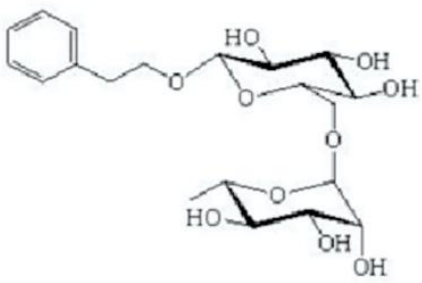

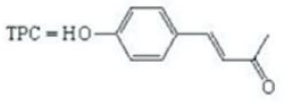<smiles>CC(O)COC(O)C(O)CC(O)C(O)O</smiles>

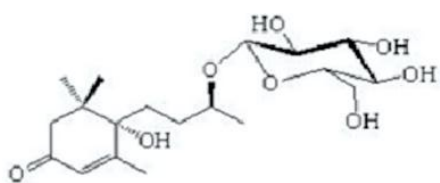<smiles>O=C(O)C1C(O)C2C(O)C=C(O)CC2OC1C1CCC(O)C(O)C1</smiles>

Şekil 2. Laden (Cistus spp.) türlerinin biyoaktif kimyasal bileşenleri. ${ }^{17,24,25}$ 
Laden türleri; farmakolojik olarak aktif alkaloidler, fenilpropanoidler (flavonoidler, fenolikler, fenolik asitler, tanninler ve ellagitanninler), aglikonlar, glikozitler, ve terpenoidler (monoterpenler, diterpenler, seskiterpenler, labdan tipi diterpenler ve klerodanlar), hidrokarbonlar (n-tetradekan, n-hekzadekan, pentakosan, pentadekan, neofitadien, heptadeken, dokosan, oktakozan, heneikosan, dodesan, neofitadien, nonacosane ve tetrakozan), yağ asitleri, karbonik bileşikler, fitohormonlar ve vitaminler gibi sekonder metabolitler intiva etmektedir. Cistus türlerinin içerdiği sekonder bileşikler ve bunların miktarları, farklı laden türlerinde değişiklik göstermekle birlikte; genel olarak bulunan bileşiklerin kimyasal yapıları Şekil $\mathbf{2}$ 'de verildiği gibidir. ${ }^{17,24,25}$

Farklı Cistus türleri ile yapılan çalışmalarda, $C$. villosus ve $C$. salviifolius uçucu yağlarının nonterpen; $C$. creticus ve $C$. monspeliensis türlerinin ise monoterpenler (myrcen terpen, lemonen ve fenol karvakrol) ve labdan-tip diterpen bileşenlerce zengin olduğu ${ }^{21}$, Cistus creticus bitkisinin kimyasal bileşiminde ise tanenler, heterozitler, triterpenler, flavonoidler ve saponozitlerin bulunduğu tespit edilmiştir. ${ }^{26}$ Türkiye'de doğal olarak yetişen $C$. salviifolius, $C$. creticus ve $C$. laurifolius türleri Türkiye florasında doğal olarak yetişen türler olup; bunlardan C. salviifolius ve $C$. creticus türlerinde trans-tilirozit (mono-coumaroyl kamferol glikozit); $C$. laurifolius türünde ise hiperin ve mirsetin flavonoidleri en yoğun bulunan flavonoidler olarak belirlenmiştir. ${ }^{27}$ Ayrıca yapılan NMR ve kütle spektroskopisi çalışmalarında Cistus türlerinin kaempferol 3-O-(3",6"-di-O-Ep-coumaroyl)-6-D-glucopyranoside, scopoletin, kaempferol 3-O-(3"-O-E-p-coumaroyl)-B-D-glucopyranoside, kaempferol 3-O-(6"-O-E-p-coumaroyl)-B-D-glucopyranoside, kaempferol 3-O-B-D-glucopyranoside, kaempferol 3-O- $\alpha$-L-rhamnopyranosyl-(1 $\rightarrow 2)-\left(6^{\prime \prime}-O-E-p\right.$-coumaroyl)-6-D-glucopyranoside, methyl flavogallonate, quercetin 3-O-B-D-glucopyranoside, quercetin 3-O-B-D-galactopyranoside, hydroquinone, arbutin, methyl B-glucopyranoside, shikimic acid, (S)-1,2-propandiol-1-O-B-D-

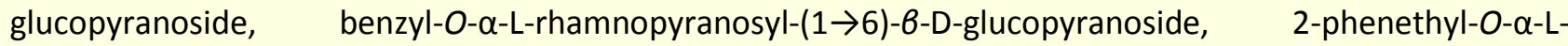
rhamnopyranosyl-(1 $\rightarrow 6)-B$-D-glucopyranoside, corchoionoside $C$ ve kaempferol 3-O- $\alpha$-L-rhamnopyranosyl$(1 \rightarrow 2)$-6-D-glucopyranoside ihtiva ettikleri belirlenmiştir. ${ }^{17,24}$

\section{Cistus Türlerinin Geleneksel Kullanımları, Biyolojik ve Farmakolojik Aktiviteleri}

Laden türlerinin çiçekleri, yaprakları ve rezin olmak üzere pek çok kısmı infüzyon şeklinde bitki çayı olarak özellikle sindirim sistemi rahatsızlıklarında ve ülserde, nezle ve soğuk algınlığında, astım, bronşit ve nefes darlığı problemlerinde, mikrobiyal enfeksiyonlarda, ağrı kesici, kas gevşetici ve sakinleştirici olarak halk hekimliğinde kullanılmaktadır. ${ }^{24}$ Laden türlerinin sahip olduğu genel biyolojik ve farmakolojik özellikleri Şekil $\mathbf{3}^{\prime}$ de özetlendiği gibidir.

Ülkemizin özellikle kıyı kesimlerinde ve makilik alanlarda C. creticus L., C. salviifolius L., C. parviflorus Lam., C. monspeliensis $\mathrm{L}$. ve $C$. laurifolius $\mathrm{L}$. olmak üzere beş farklı Laden türü doğal olarak yetişmekte ve bu türler yöresel olarak 'Kaya gülü', 'Pamucak', 'Pamukluk', 'Karağan', 'Karahan', 'Davşanotu' ve 'Tavşancıl' gibi farklı isimler ile bilinmektedir. Bu türlerin yaprakları rezin, uçucu yağ ve tanen bakımından zengin olduğundan; Anadolu Halk Hekimliğinde infüzyon (\%5) halinde ishal edici, uyarıcı ve balgam söktürücü olarak kullanılmaktadır. C. laurifolius L. türünün yaprakları, oleoresin ve uçucu yağı ise, infüzyon (\%2) olarak, Konya ve civarında şeker hastalığına karşı ve ayrıca renk veren özelliğinden dolayı yün boyamada kullanılmaktadır. ${ }^{1,22,28}$ Aromatik ve uyarıcı özelliklerinin yanı sıra; C. laurifolius L. türü, kanamayı durdurucu, mukus salgısını arttıııı, balgam söktürücü ve antibiyotik etkilere de sahip olduğundan tıbbi olarak da kullanım alanına sahiptir. Türkiye'de fumigant olarak kullanıldığı belirtilen bitkinin; ayrıca parfümlerde fiksatif olarak, unlu mamuller, alkolsüz içecekler, dondurma ve şeker üretiminde gıda maddelerine aroma verici olarak kullanıldığı da bildirilmiştir. ${ }^{3,20}$ 


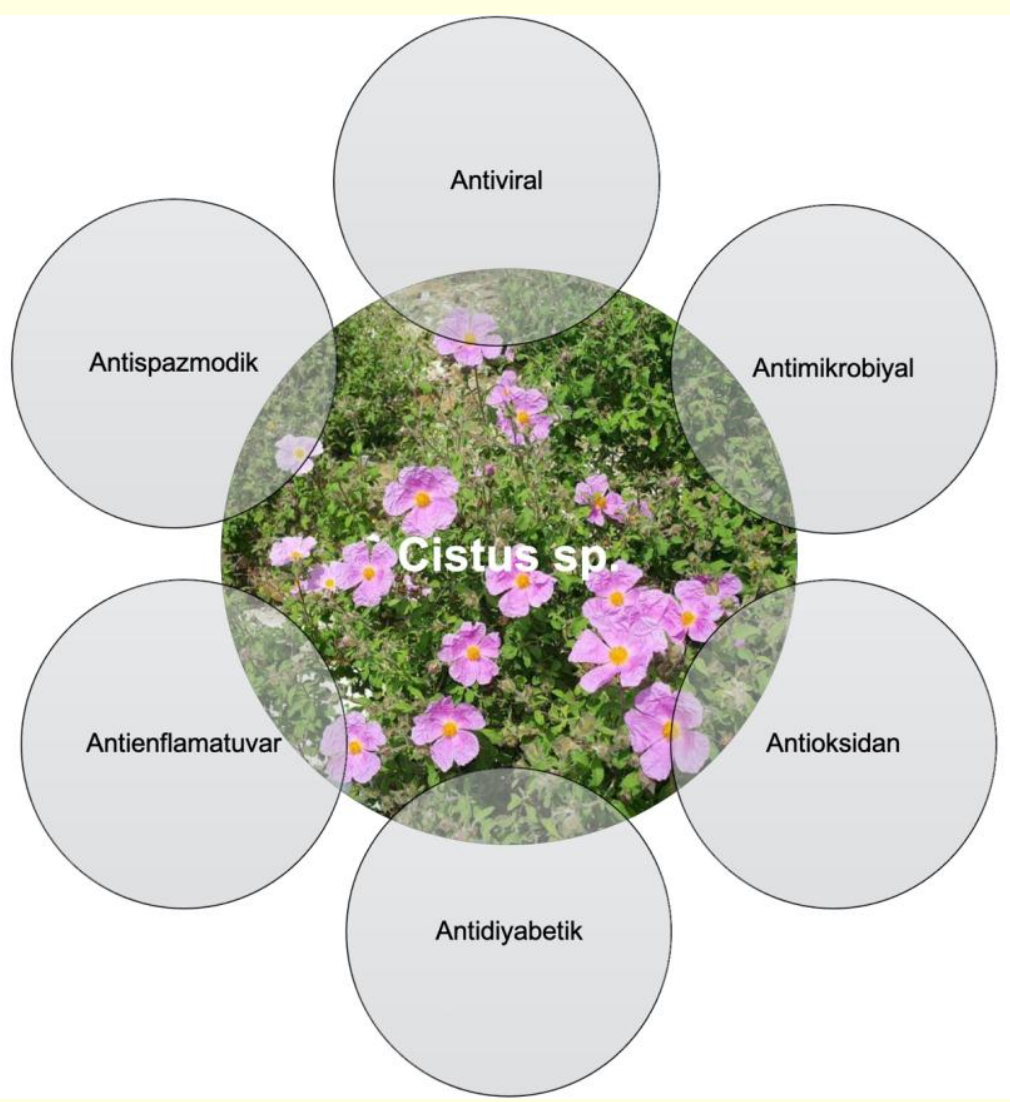

Şekil 3. Laden (Cistus spp.) türlerinin genel olarak biyolojik ve farmakolojik özellikleri

Cistus türlerinin değişik oranlarda yararlı fitokimyasal maddeler içerdiği ve bu sayede güçlü antiviral, antialerjik, antioksidan, antibakteriyel, antifungal, antiseptik, antienflamatuvar, antikanser, sitotoksik, gastroprotektif, kardiyoprotektif ve dermoprotektif özelliklere sahip olduğu yapılan çalışmalarda rapor edilmiştir. 3,17,29,30 Ülkemizde doğal olarak yetişen C. creticus L. bitkisi zengin polifenolik madde içeriği sayesinde antibakteriyel, antioksidan ve DNA koruyucu etkilere sahip olduğu da gösterilmiştir. ${ }^{31}$ Laden türleri ile ilgili yapılan başka bir çalışmada; bitkinin antioksidan kapasitesi yeşil çay ile kıyaslanmış ve yeşil çaydan daha yüksek antioksidan kapasiteye sahip olduğu ortaya konulmuştur. Cistus bitkisi ile yeşil çayın polifenol içeriği bakımından da kıyaslandığı bu çalışmada, her iki bitkiden elde edilen ekstrelerin zengin polifenol içeriğe sahip oldukları ve bu sayede oldukça güçlü antibakteriyel, antifungal ve antienflamatuvar aktiviteler gösterdikleri belirtilmiştir. ${ }^{32}$ Bunun yanı sıra, üst solunum yolu enfeksiyonları ile ilgili olarak 160 hasta üzerinde gerçekleştirilen klinik bir araştırmada, Cistus bitkisinden elde edilen bitkisel ilaç (Cistus incanus PANDALIS ${ }^{\circledR}$ (CYSTUSO52 $^{\circledR}$ ) ile tedavi edilen hasta sayısının yeşil çaydan elde edilen bitkisel ilaca $\left(\right.$ Morgentau $^{\circledR}$ ) göre daha yüksek olduğu gösterilmiştir. ${ }^{33}$

Türkiye'de doğal olarak yetişen laden türlerinin; meyveli yapraklarından su, metanol, kloroform, etil asetat ve bütanol çözücüleri ile farklı ekstreler elde edilmiş ve bu ekstrelerin antimikrobiyal ve antifungal etkinlikleri farklı mikroorganizmalara [Staphylococcus aureus (ATCC 29213 ve ATCC 25923), Streptococcus faecalis (ATCC 29212), Bacillus subtilis (ATCC 6633), Bacillus cereus (RSKK 1122), Pseudomonas aeruginosa (ATCC 27853), Escherichia coli (ATCC 25922) ve Candida albicans (ATCC 10231)] karşı test edilmiştir. Yapılan bu araştırmada, laden türlerinden elde edilen bitki özütlerinin $P$. aeruginosa ve $C$. albicans dışında incelenen tüm mikroorganizmalara karşı etkili olduğu sonucuna varılmıştır. ${ }^{34}$

İtalya'nın Sardunya şehrinde yetişen farklı C. creticus L. alt türleri ile ilgili olarak, fenolik bileşimi karakterize etmek ve Sardunya'da büyüyen antimikrobiyal aktivitelerini değerlendirmek amacıyla bir çalışma yapılmıştır. Çalışmada bitkilerin taze hava kısımları asitleştirilmiş metanol kullanılarak ekstrakte edilmiş ve 
elde edilen ekstraktlardaki polifenoller HPLC ile tanımlanmıştır. Antimikrobiyal aktivite analizleri ise, agar makrodilüsyon yöntemi kullanılarak Minimum İnhibisyon Konsantrasyonlarına (MiK) göre belirlenmiştir. Bitkinin farklı alt türlerinde kısmen farklılık göstermekle birlikte; fenolik asitler, monomerik ve dimerik flavan-3-oller, flavonol glikozitler dâhil 52 fenolik bileşik saptanmıştır. Bununla birlikte farklı alt türlerden elde edilen özütler arasında antimikrobiyal aktiviteler yönünden belirgin bir farklılık gözlenmemiştir; Grampozitif bakterilerin Cistus ekstrelerine Gram-negatif bakterilere göre daha duyarlı olduğu belirlenmiştir. ${ }^{35,36}$

Tunus'ta gerçekleştirilen bir çalışmada, $C$. salviifolius L. ve $C$. monspeliensis L. türlerinin yaprak ve çiçek kısımlarından elde edilen özütlerin antibakteriyel ve antifungal aktiviteleri analiz edilmiştir. Özütler, Grampozitif (Listeria monocytogenes, Bacillus subtilis ve Staphylococcus aureus), Gram-negatif bakteriler (Salmonella enteric, Pseudomonas aeruginosa ve Escherichia coli), ve patojenik mantarlara (Candida albicans ve Aspergillus niger) karşı antibakteriyel ve antifungal aktiviteleri disk difüzyon yöntemi ile analiz edilmiştir. Çalışmaya dâhil edilen Cistus türlerinden C. salviifolius L. türünün daha güçlü antibakteriyel aktivite gösterdiği belirlenmiş; hatta standart antibiyotik olarak kullanılan gentamisin'den dahi daha yüksek oranda mikroorganizma gelişimini engelleme potansiyeline sahip olduğu tespit edilmiştir. Buna ek olarak, bitki özütlerinin C. albicans mantarına karşı da oldukça yüksek antifungal aktivite sergilediği rapor edilmiştir. ${ }^{37}$ Rebaya ve ark. tarafından C. salviifolius L. bitki türünün etanol, bütanol, etil asetat, diklorometan ve su özütlerin toplam polifenolik madde içeriğinin belirlenmesi ve antioksidan kapasitesinin ortaya konulmasına yönelik yapılan diğer bir çalışmada da su özütlerinin yüksek fenolik, flavanoid ve proantosiyanidin içeriğe sahip olduğu gösterilmiştir. Bitkinin çalışılan tüm özütlerinin güçlü antioksidan aktiviteye sahip olduğu belirlenirken; su ve etanol özütlerinin antioksidan kapasitelerinin en yüksek olduğu gözlenmiştir. ${ }^{38}$

Cezayir'de yetişen C. salviifolius L. bitkisinin uçucu yağı ile yapılan bir çalışmada ise bitki uçucu yapının test edilen gram pozitif ve gram negatif bakteri suşlarına karşı geniş spektrumlu antimikrobiyal bir ajan olduğu tespit edilmiştir. ${ }^{39}$

Yapılan bir başka çalışmada, Yunanistan'a endemik C. creticus L. (kaya gülü) arı poleninin serbest radikal süpürme aktivitelerinin tanımlanması, kimyasal bileşimlerinin, fenolik ve flavanoid içeriklerinin belirlenmesi amaçlanmıştır. Bitki özütlerinin kimyasal analizlerinde quercetin-7-ramnoside (1), quercetin-3neohesperidoside (2), kaempferol-3-neohesperidoside (3), myricetin-3-neohesperidoside (4), kaempferol-3glukozit (5) ve quercetin-3-glukozit (6) izole edilmiştir. Ayrıca yüksek fenolik ve flavonoid madde içerikleri ile serbest radikal süpürme kapasitelerine sahip oldukları da ortaya konulmuştur. ${ }^{40}$

Daha sonra yapılan bir çalışmada ise; Fas'ta yetişen C. creticus L. türünün yapraklarından elde edilen uçucu yağ ile yaprak ekstraktının flavonoidler, tanenler, saponinler ve alkaloidler olmak üzere farklı fraksiyonlarının toplam fenolik içeriği, antioksidan ve antibakteriyel özellikleri incelenmiştir. İncelenen farklı ekstraktların antioksidan kapasiteleri bakımından flavonoidler ve saponinler için diğer ekstraktlara kıyasla anlamlı derecede yüksek olarak saptanmıştır. Ham ekstraktlar ve uçucu yağlar antimikrobiyal ve antifungal aktiviteleri açısından değerlendirildiğinde ise, bitkinin ihtiva ettiği labdan diterpenler (manyol oksit ve 13 pi epi-manoil oksit) ve diterpenoidlerin Staphylococcus aureus ve S. epidermidis, Pseudomonas aeruginosae, Enterobacter cloaceae, Klebsiella pneumonia, Escherichia coli bakterilerine karşı antibakteriyel ve Candida albicans, C. glabrata, Saccharomyces cerevisiae mantar suşlarına karşı antifungal aktiviteler gösterdiği belirlenmiştir. ${ }^{18}$

Rauwald ve ark. tarafından gerçekleştirilen araştırmada; C. creticus L. bitkisinin fitokimyasal olarak bileşiminde var olan manoiloksit (A), 3-asetoksi-manoyloksit (B), 3 - hidroksi-manoyloksit (C), epi manoyloksitin (D) 2-keto-manoiloksit (E) ve sklareol (F) izole edilmiş ve etken maddelerin Lyme hastalığına neden olan Borrelia burgdorferi'ye karşı anti-Borrelia aktiviteye sahip olup olmadığı test edilmiştir. İ̧̧erdiği 
bazı etken maddelerin göstermiş olduğu güçlü anti-Borrelia aktivitelerinden dolayı; C. creticus L. bitkisinin Lyme hastalığının tedavisinde kullanılma potansiyelinde olduğu öngörülmüştür. ${ }^{25}$

C. salviifolius L. ve $C$. monspeliensis L. türlerinin toprak üstü kısımlarından elde edilen su ve hidrometanolik özütlerin antioksidan aktiviteleri, mineral ve fenolik madde içerikleri belirlenmiş, ayrıca diyabet hastalarında hiperglisemi gelişimi ile yakından ilişkili olan $\alpha$-amilaz ve $\alpha$-glukosidaz enzimlerinin çalışmalarını engelleyici özelliğe sahip olup olmadıkları in vitro modeller üzerinde test edilmiştir. Her iki bitki türünün de yüksek mineral ve fenolik madde içeriğine sahip olduğu belirlenmiştir. Özütlerin, $\alpha$-glukosidaz enzim faaliyetini $\alpha$ amilaz enzimine göre daha fazla inhibe ettiği de varılan sonuçlar arasında sunulmuş olup; hiperglisemi tedavisi için umut vaat eden bitki türleri olduğu rapor edilmiştir. ${ }^{41}$

C. salviifolius L. ve C. monspeliensis L. türlerinin in vivo anti-inflamatuvar ve analjezik aktivitelerini ortaya koymak amacıyla Salah ve ark. tarafından yapılan bir diğer çalışmada ise; bitkilerin su ile elde edilen özütlerinin merkezi ve periferal olarak analjezik aktivite gösterdiği ve ayrıca antienflamatuvar özelliğe sahip olduğu Swiss cinsi fareler ve Wistar cinsi ratlar ile oluşturulan hayvan modellerinde gösterilmiştir. ${ }^{41}$ Bitki türlerinin ihtiva ettiği yüksek fenolik, polifenolik ve antioksidan bileşiklerin; bitkinin güçlü antienflamatuvar kapasitesine ciddi ölçüde katkı sağlamış olabileceği düşünülmektedir. ${ }^{42}$

\section{Sonuç ve Öneriler}

Ülkemizde doğal olarak beş farklı türü ile yayılış gösteren; etnobotanik kullanımının yanı sıra Anadolu Halk Hekimliğinde geleneksel halk ilacı olarak yüzyıllardır çeşitli hastalıkların tedavisinde kullanılagelen, günümüzde de gıda, ilaç ve endüstriyel amaçlarla kullanılma potansiyeli bulunan Laden (Cistus spp.) türlerinin biyolojik aktivitelerinin belirlenmesi, içerdikleri etken maddelerin ortaya konulması, belirlenen etken maddelerin farmasötik alanda ilaç ham maddesi olarak kullanımı ve böylece bitkisel tedavi olanaklarının oluşturulması son derece önemlidir. Doğal floramızdan her yıl tonlarca toplanarak yurtdışına gönderilen bu kıymetli bitkiye sahip çıkılması ve özellikle de COViD-19 tedavi sürecine dahil edilerek muhtemel antiviral ilaç üretiminde araştırılması gereken bir bitkidir. Avrupa'da antiviral pastil ve kış çaylarının karışımında yoğun olarak kullanılan Cistus bitkisine gereken önemin bir an önce verilmesi ulusal ilaç geliştirme politikamız açısından da hayati bir öneme sahiptir. Son yüzyılda görülme sıklığı ve ölüm oranı ciddi oranda artış gösteren ve insanların yaşam kalitesini olumsuz yönde etkileyen kanser, diyabet, kardiyovasküler hastalıklar ve nörodejeneratif bozuklukların tedavisinde de Cistus türlerinin yüksek antioksidan kapasitesi ve zengin fitokimyasal içerikleri ile değerlendirilmesi gerektiği ortaya çıkmaktadır. Sonuç olarak; sunulan bu derleme ile, zengin biyolojik aktiviteye ve farmakolojik özelliklere sahip, önemli bir tıbbi bitkimiz olan laden türlerine ve bu türlerden elde edilebilecek ilaç etken maddelerine vurgu yapılarak, bu bitki türleri ile ilgili daha sonra yapılacak olan in vivo araştırmalara ışık tutacak ve farmasötik alanda geliştirilecek olan ilaç hedeflerine katkı sağlayacak güncel veriler sunulmuştur.

\section{Bilgi}

Yazarlar finansal veya başka bir yolla herhangi bir çıkar çatışmalarının olmadığını beyan ederler.

\section{Araştırmacı Katkı Oranı Beyanı}

Nazım Şekeroğlu: Fikir/kavram, denetleme/danışmanlık, kaynak taraması, makalenin yazımı, eleştirel inceleme.

Sevgi Gezici: Denetleme/danışmanlık, kaynak taraması, makalenin yazımı, eleştirel inceleme. 


\section{Kaynaklar}

1. Baytop T. Türkiye'de bitkilerle tedavi - Geçmişte ve bugün, Nobel Tıp Kitabevleri, ilaveli II. Baskı, 1999; İstanbul.

2. Kim C, Kim B. Anti-cancer natural products and their bioactive compounds inducing ER stress-mediated apoptosis: A review. Nutrients 2018;10(8):1-29.

3. Sekeroglu N, Gezici S. Coronavirus pandemic and some Turkish medicinal plants. Anatol Clin J Med Sci 2020;25(Special issue on COVID19):163-82.

4. Jellin JM, et al. Pharmacist's letter/prescriber's letter natural medicines comprehensive database. $4^{\text {th }}$ ed. Stockton, CA: Therapeutic Research Facility 2002;103-5.

5. Shan $\mathrm{M}$, et al. A review on the phytochemistry, pharmacology, pharmacokinetics and toxicology of geniposide, a natural product. Molecules 2017;22(10):1689-1718.

6. Enquist LW. Virology in the $21^{\text {st }}$ century. J Virol 2009;83(11):5296-308.

7. Leal ÉDS, Zanotto PMDA. Viral diseases and human evolution. Memórias do Instituto Oswaldo Cruz. 2000;95:193-200.

8. Gezici S, Sekeroglu N. Novel SARS-CoV-2 and COVID-2019 outbreak: Current perspectives on plant-based antiviral agents and complementary therapy. Ind J Pharm Educ Res 2020;54(3s):442-56.

9. NIH (National Institutes of Health) / U.S. National Library of Medicine, COVID-19 is an emerging, rapidly evolving situation. 2020. Accessed from; https://www.nih.gov/coronavirus. Accessed date 28 December, 2020.

10. Woolhouse M, et al. Human viruses: discovery and emergence. Philos Trans R Soc Lond B Biol Sci 2012;367(1604): 2864-71.

11. Cheever FS, et al. A murine virus (JHM) causing disseminated encephalomyelitis with extensive destruction of myelin: I. isolation and biological properties of the virus. J Exp Med 1949;90(3):181.

12. Geller C, Varbanov M, Duval RE. Human coronaviruses: insights into environmental resistance and its influence on the development of new antiseptic strategies. Viruses 2012;4(11):3044-68.

13. Walsh EE, Shin JH, Falsey AR. Clinical impact of human coronaviruses $229 \mathrm{E}$ and OC43 infection in diverse adult populations. J Infect Dis 2013;208(10):1634-42.

14. Pillaiyar T, Meenakshisundaram S, Manickam M. Recent discovery and development of inhibitors targeting coronaviruses. Drug Discov Today 2020;1-21.

15. Greenwell M, Rahman PKSM. Medicinal plants: their use in anticancer treatment. Int J Pharm Sci Res 2015;4103.

16. Roy A, Jauhari N, Bharadvaja N. Medicinal plants as anticancer plants: natural products and biotechnological implements. 2018;2:109-139, Springer, Singapore.

17. Fang X, et al. Chemical constituents from the leaves of Cistus parviflorus. J Chin Pharm Sci 2018;27(1):40-50.

18. Lahcen SA, et al. Chemical composition, antioxidant, antimicrobial and antifungal activity of Moroccan Cistus creticus leaves. Chem Data Collec 2020;26:100346.

19. TPL (The Plant List) Version 1.1. Published on the Internet; Accessed from; http://www.theplantlist.org/ http://www.theplantlist.org/browse/A/Cistaceae/ Accessed date: 11 November, 2020.

20. Bown D. Encyclopedia of herbs and their uses, the herb society of America, 2004;167:16-8, Darling, Kindersley, London.

21. Politeo $O$, et al. Phytochemical composition and antimicrobial activity of essential oils of wild growing Cistus species in Croatia. Nat Prod Commun 2018;13(6):771-4.

22. TUBIVES (Türkiye Bitkileri Veri Servisi) Version 2.0 BETA. Accessed from; http://www.tubives.com/ Accessed date 11 December, 2020.

23. Kuchta K, et al. The old pharmaceutical oleoresin labdanum of Cistus creticus L. exerts pronounced in vitro anti-dengue virus activity. J Ethnopharm 2019;112316.

24. Papaefthimiou D, et al. Genus Cistus: a model for exploring labdane-type diterpenes' biosynthesis and a natural source of high value products with biological, aromatic, and pharmacological properties. Front Chem 2014;2: 35.

25. Rauwald HW, et al. Labdanum and Labdanes of Cistus creticus and C. ladanifer: Anti-Borrelia activity and its phytochemical profiling. Phytomed 2019;60:152977.

26. Sahraoui R, Djellali S, Chakera AN. Morphological, anatomical, secondary metabolites investigation and physicochemical analysis of Cistus creticus. Pharm Commun 2013;3(4):58-63.

27. Gurbuz P, et al. Simultaneous determination of selected flavonoids from different Cistus species by HPLC-PDA. Marmara Pharm J 2018;22(3):405-10.

28. Coode MJE, et al. (Ed.). Flora of Turkey and the East Aegean Islands. 1988; 10, Edinburgh University Press. Edinburgh, UK. 61p

29. Stępień A, Aebisher D, Bartusik-Aebisher D. Biological properties of “Cistus species". Eur J Clin Exp Med 2018;16(2):127-32.

30. Stępień AE, Ewa A. Cytotoxic and anti-cancer activity of the Cistus species of herbal plants. Eur J Clin Exp Med 2017;(2):165-8.

31. Kilic DD, et al. Antibacterial, Antioxidant and DNA İnteraction Properties of Cistus creticus L. Extracts. J Int Environ Appl Sci 2019;14(3):110-5.

32. Jeszka-Skowron M, Zgoła-Grześkowiak A, Frankowski R. Cistus incanus a promising herbal tea rich in bioactive compounds: LCMS/MS determination of catechins, flavonols, phenolic acids and alkaloids-A comparison with Camellia sinensis, Rooibos and Hoan Ngoc herbal tea. J Food Compos Anal 2018;74:71-81.

33. Kalus U, et al. Cistus incanus (CYSTUS052) for treating patients with infection of the upper respiratory tract A prospective, randomised, placebo-controlled clinical study. Antiviral Res 2009;84:267-71.

34. Guvenc A, et al. Antimicrobiological studies on Turkish Cistus species. Pharm Biol. 2005;43(2):178-83.

35. Mastino PM, et al. Analysis and potential antimicrobial activity of phenolic compounds in the extracts of Cistus creticus subspecies from Sardinia. J Nat Prod 2018a;8(3):166-74.

36. Mastino PM, et al. Interpopulation variability in the essential oil composition of Cistus creticus subsp. eriocephalus from Sardinia. Chem Biodivers 2018b;15(9):e1800151. 
37. Rebaya A, et al. Antibacterial and antifungal activities of ethanol extracts of Halimium halimifolium, Cistus salviifolius and Cistus monspeliensis. Int J Pharm Clin Res 2016a;8(4):243-7.

38. Rebaya A, et al. Total phenolic compounds and antioxidant potential of rokrose (Cistus salviifolius) leaves and flowers grown in Tunisia. Int J Pharmacogn Phytochem Res 2016b;8:327-31.

39. Nadjet M, et al. Study of the chemical composition, antimicrobial activity of the essential oil of Cistus salviifolius from Tissemsilt National Park (Algeria) and influence of the drying period in the shade on the yield of this oil. South Asian J Exp Biol 2020;9(6):238-44.

40. Atsalakis E, et al. Evaluation of phenolic compounds in Cistus creticus bee pollen from Greece. Antioxidant and antimicrobial properties. Nat Prod Commun 2017;12(11):1934578X1701201141.

41. Sayah K, et al. Antioxidant activity and inhibitory potential of Cistus salviifolius (L.) and Cistus monspeliensis (L.) aerial parts extracts against key enzymes linked to hyperglycemia. BioMed Res Int 2017a; 2017:1-7.

42. Sayah K, et al. In vivo anti-inflammatory and analgesic activities of Cistus salviifolius (L.) and Cistus monspeliensis (L.) aqueous extracts. S Afr J Bot 2017b;113:160-3. 